\title{
Qualidade Higiênico-Sanitária de Cachorros-Quentes Comercializados em Pontos de Venda Informais de Alimentos em Canoinhas-Sc.
}

\author{
Gislaine Aparecida Becker (I), Lucas Muenster Machado (I), Juliana \\ Kmiecik (I), Jucelino Deller (I), Claudete Maria de Souza (I), \\ Graciele Viccini Isaka (I) \\ (I) IFSC - Instituto Federal de Santa Catarina - IFSC Campus Canoinhas (Av. Expedicionários, \\ 2150, Campo da Água Verde, Canoinhas, SC)
}

\section{Resumo}

O cachorro-quente é o lanche popular mais vendido por ambulantes. $\mathrm{O}$ comércio de alimentos em vias públicas é um risco à saúde da população, pois os produtos podem ser contaminados com microrganismos patogênicos, devido às condições inadequadas do local de preparo e à falta de conhecimento sobre Boas Práticas de Manipulação de Alimentos (BPM) pelos comerciantes. O objetivo do trabalho foi avaliar a qualidade de cachorros-quentes em 5 pontos de venda informais em Canoinhas-SC, por meio de (1) entrevista, (2) avaliação da qualidade microbiológica do ar ambiente, da superfície do equipamento e das mãos dos manipuladores, e (3) avaliação da qualidade microbiológica do cachorro-quente. Os resultados foram comparados com a RDC $n^{\circ} 12$ de 2001/ANVISA e artigos científicos. Notou-se que $100 \%$ dos entrevistados são donos do estabelecimento, armazenam salsicha em isopor com gelo, depositam lixo em lixeiras públicas, e não têm acesso a banheiro, $60 \%$ dos vendedores são homens; têm mais de 40 anos e trabalham no carrinho a menos de 5 anos; $40 \%$ limpam os equipamentos a cada hora; $60 \%$ retiram o lixo quando a lixeira está cheia; e $60 \%$ manipulam dinheiro e alimento (20\% com luva e $40 \%$ sem luva). A higiene dos equipamentos é feita com detergente $(60 \%)$ ou detergente e álcool (40\%). Dos vendedores, $100 \%$ nunca fizeram cursos de BPM e sua compreensão restringe-se a material branco e luvas;

\footnotetext{
Referência:

Gislaine Aparecida Becker, Lucas Muenster Machado, Juliana Kmiecik, Jucelino Deller, Claudete Maria de Souza, Graciele Viccini Isaka.Qualidade Higiênico-Sanitária de Cachorros-Quentes Comercializados em Pontos de Venda Informais de Alimentos em Canoinhas-Sc.. In: Anais do 12을 Congresso Latinoamericano de Microbiologia e Higiene de Alimentos - MICROAL 2014 [= Blucher Food Science Proceedings, num.1, vol.1]. São Paulo: Editora Blucher, 2014. 
conservar salsicha e pão; higiene; alimentos frescos e gelo. Outras irregularidades observadas: uso de esmalte e adornos; lixeiras próximas com insetos; panos sujos na manipulação; e vendedor com conjuntivite. $\mathrm{Na}$ avaliação do ar ambiente, $80 \%$ apresentaram contaminação por bactéria acima do padrão (até $30 \mathrm{UFC} / \mathrm{cm} 2 /$ semana), demostrando que vias públicas podem disseminar microrganismos. Na avaliação das mãos dos manipuladores, $20 \%$ apresentaram resultados acima do limite $(2 \times 103$ UFC/mão) e nas superfícies do equipamento, todos estavam de acordo com os limites (até 2 UFC/cm2). Nas análises microbiológicas, 100\% das amostras estavam acima do padrão permitido para bactérias aeróbias mesófilas, e 83,3\% para Estafilococus coagulase positiva. Detectou-se possível presença de Salmonella ssp em 100\% das amostras. Os resultados negativos são reflexos da falta de capacitação e de treinamento, e do restrito conhecimento sobre as BPM de alimentos pelos vendedores de cachorro-quente.

Palavras-Chave: Lanches, Microrganismos, Vendedores ambulantes Agência de Fomento: CNPQ (PIBIC/EM) 